原著論文

\title{
歯科骨内インプラント法への微小電流刺激の応用
}

\author{
第 1 報＼cjkstart微小電流刺激装置および電極の試作
}

\author{
守屋 光孝 田中 久敏
}

\section{Experimental Study on the Application of Direct Current to the Intra-Osseous Implant}

\author{
Mitsutaka Moriya and Hisatoshi Tanaka
}

\begin{abstract}
The purpose of this study is to investigate the effect of the direct current electrical stimulation on surrounding tissue of the intra-osseous implant. The implant was composed of a peripheral hydroxyapatite layer and a central metal which was used as electrodes, and applied $10 \mu \mathrm{A}$ constant direct current. They were implanted in femuls of four guinea pigs. These results were as follows :

1. When the bone marrow is stimulated electrically with $10 \mu \mathrm{A}$ direct current for 28 days, large amount of bone formation around the implant was seen in wide area.

2. There was a different reaction surrounding tissue between cathode and anode. Around the cathode, bone formation on the surface of the implant was recognized remarkably. Around the anode, little amount of bone formation on the surface of the implant was recognized.

3. The electrical stimulation, with newly developed power unit and electrode, accelerated new bone formation.
\end{abstract}

Key words : direct current, electrode, dental implant, bone formation

\section{I. 緒 言}

近年, 歯科領域では歯の衰失による咀嚼機能障害を回 復するために, 補緅治療として歯科インプラント法が応 用されつつある ${ }^{1 \sim 3)}$. 骨内インプラント法を成功させる

岩手医科大学歯学部歯科補緅学第一講座（指導：田中久敏教 授)

Department of Removable Prosthodontics, School of Dentistry, Iwate Medical University (Director: Prof. Hisatoshi Tanaka)

平成元年 10 月 9 日受付
ためには，埋植当初にインプラント周囲が骨によって初 期固定が十分になされること，さらに最終的にインプラ ントに加わる機能的負荷を支持するだけの骨量がインプ ラント周囲に存在しなければならないとされている4). しかし現在，インプラント周囲の骨を早期にしかも積極 的に緻密化する試みは少ない4 6).

1953 年に保田は，骨に荷重を加えることにより圧縮部 が電気的に陰性となり7), 同部に骨の添加形成が生じる ことを報告し ${ }^{8)}, 1955$ 年には家鬼の大腿骨に, 数週間持続 的に微小電流刺激を与えることにより電極周囲に骨が添 加形成されることを報告した ${ }^{9)}$.その後, 骨に対し微小電 


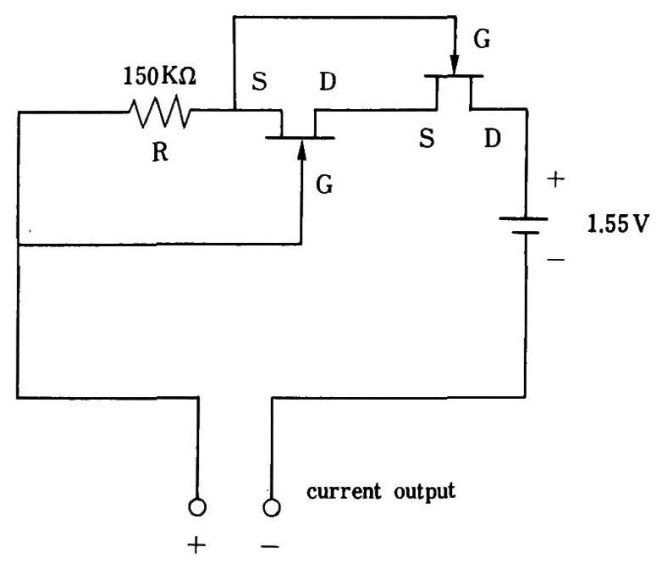

图 1 FET を用いた定電流回路

D. ドレイン；G. ケ゚ート；S. ソース；R．抵抗

流刺激を与えた多くの研究がなされ 10 23), 微小電流刺激 を与えない場合と比較して, 微小電流刺激を与えた陰極 周囲に顕著な骨形成がみられることが確認された。 これ らの研究結果をもとにして, 整形外科領域では骨折治療 に微小電流刺激が臨床応用されるにいたっている24 26).

そこで, 著者らは早期にインプラント周囲に骨形成が 望まれる骨内インプラント法に, 微小電流刺激を応用す ることを考えた. 微小電流刺激を与える電極は, インプ ラント適用部位に直接刺入されることが望ましいが，歯 の欠損部位にインプラントが埋入されるため同部には電 極を直接刺入できない，したがって著者らは, 微小電流 刺激を骨内インプラント法に応用するにあたり, 電極と インプラントを一体化した構造のインプラント体と狭小 な口腔内に装着できる小型の微小電流刺激装置を試作し た.この電極を兼椱えたインプラント体をモルモット の大腿骨に埋植し, 微小電流刺激を与え, 微小電流刺激 がインプラント体周囲の骨形成にどのような影響を及ぼ すかについて, 病理組織学的に検索を行ったので, その 結果を報告する. なお，本論文ではインプラント体を顎 骨に挿入し，粘膜下に植立することを埋植するとし，埋 植するために形成した窩を埋植窩という.

\section{II. 実験材料}

1. 微小電流刺激装置およびインプラント体の試作

1) 微小電流刺激装置

微小電流刺激装置は Friedenberg $5^{10)}$ の装置を参考 にし, field effect transistor (以下 FET と略す) を用い て定電流回路とした (図 1). 電源には $1.55 \mathrm{~V}$ の酸化銀

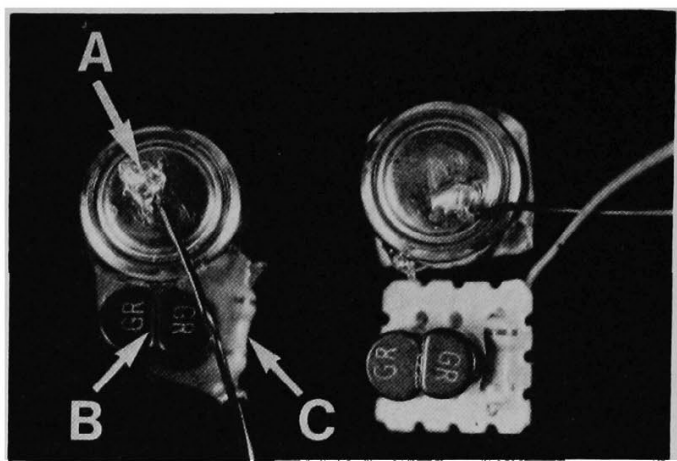

図 2 基板を用いた回路（右）と実際に作製した回路（左） A. 酸化銀電池 ; B. FET ; C. 抵抗

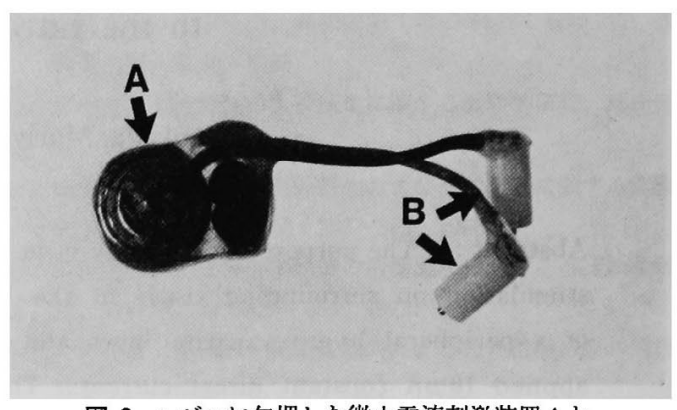

図 3 レジンに包埋した微小電流刺激装置 $\mathrm{A}$ と 連結前の電極 (インプラント体) B

電池を用い, $150 \mathrm{k} \Omega$ の抵抗を接続し $10 \mu \mathrm{A}$ の刺激電流 とした (図 2). また微小電流刺激装置は矯正用レジン （三金工業社製）を用いて包埋し，絶縁を行った (図 3). その結果, 装置は重量約 $5 \mathrm{~g}$ で, $9 \times 13 \times 18 \mathrm{~mm}$ 程度の 大きさとなった.

2）電極拉よびインプラント体

実験に用いたインプラント体の構造は, インプラント としての機能のほかに周囲組織に微小電流刺激を与える 電極の機能を兼敉備えたものを考案した. すなわち, 電 極には, 直径 $1 \mathrm{~mm}$, 長さ $5.5 \mathrm{~mm}$ の歯科用白金加金線 (Au 66.0\%, Pt 11.0\%, Pd 6.0\%, Ag 6.0\%, Cu 9.5\%) を用いた. この電極の両端各 $1 \mathrm{~mm}$ を残し, 中央部 3.5 $\mathrm{mm}$ の周囲を厚さ $1 \mathrm{~mm}$ の相対密度 $99 \%$ 以上のハイド ロキシアパタイト(旭光学社製) で覆い(図4), 図 5 に 示すように全体を直径 $3 \mathrm{~mm}$ の円柱状のインプラント体 とした (図 5). 各インプラント体の一端を微小電流刺激 装置からの電線とろう着し，2本のインプラント体を 15 $\mathrm{mm}$ の間隔で矯正用レジンを用い絶縁し，それぞれを連 結して陽極と陰極とした（図6，7）. 


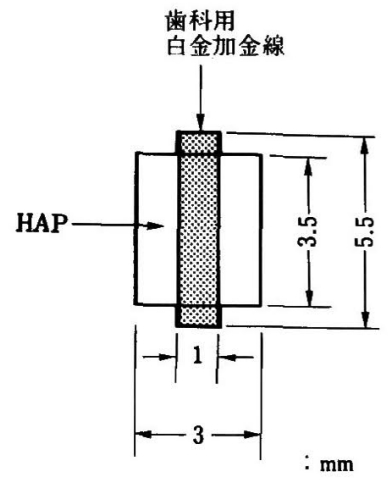

図 4 電極 (インプラント体) の 寸法図

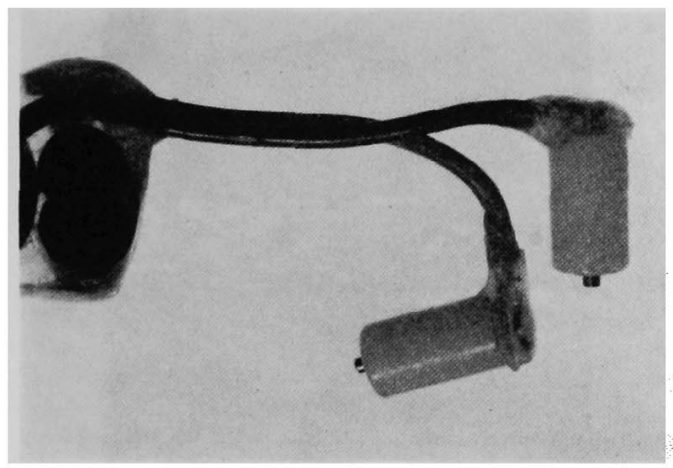

図 5 電極 (インプラント体) 部の桩大

\section{III. 実験方法}

\section{1. 実験動物}

実験には，十分に成長したと思われる 20 週齢の Hartley 系雄性モルモット（体重 $800 \mathrm{~g}$ 前後）4羽を用い た.

\section{2. インプラント体の埋植およひ微小電流刺激装置の} 装着

インプラント体の埋植および微小電流刺激装置の装着 にあたっては, Pentobarbital $38 \mathrm{mg} / \mathrm{kg}$ 腹腔内注射によ り麻醉を施した. その後, モルモットを仰卧位に固定し て大腿部皮盧および筋組織を切開剝離し，大腿骨を露呈 させた.ついで，骨膜を剥離した後，大腿骨骨幹部中央 に $15 \mathrm{~mm}$ の間隔を開けて 2 力所に直径 $3 \mathrm{~mm}$, 深さ 3.5 $\mathrm{mm}$ のインプラント体埋植窩を形成した. 埋植窩の形成 は, 直径 $2.9 \mathrm{~mm}$ のトレパンおよびフィッシャーパーを $300 \mathrm{rpm}$ 以下の回転数で, 生理食塩水を注水しながら娋

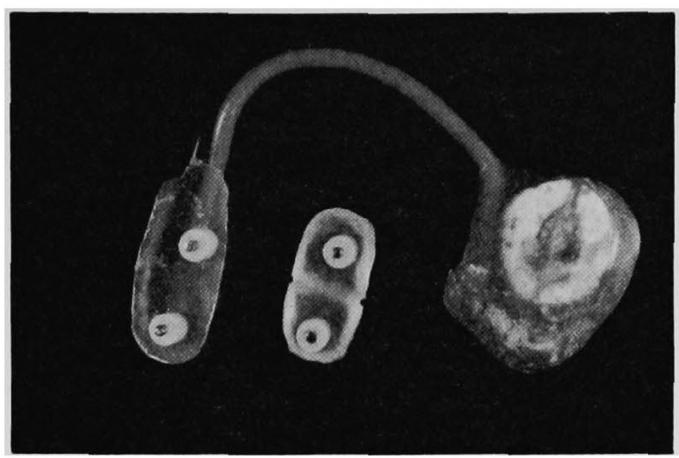

図 6 連結した電極と微小電流刺激装直

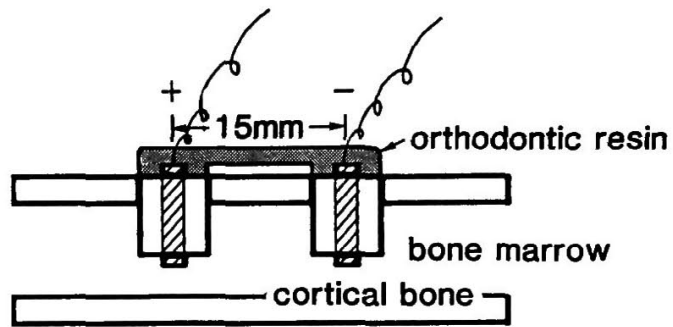

図 7 骨内に植立した電極周囲の模式図

に発熱を起こさないよう注意して行った. インプラント 体は大腿骨の近位端側の埋植窝に陽極を，遠位端側の埋 植窩に陰極を手圧にて埋植した。 また，埋植初期の動摇 や脱落を防ぐため，連結したインプラント体と大腿骨の 周囲を絹采で結禁固定し（図 8)，創部を 縫 合した。な お，微小電流刺激装置は皮下を通して背部に装着した (図 9).

\section{3. 観察期間}

微小電流刺激装惪と接続したインプラント体を埋植 し，微小電流刺激を行ったものを実験群とし，インプラ ント体を埋植したのみのものを対照群とした，観察期間 は，インプラント体埋植後 28 日目とした. また，骨動 態の変化を経時的に観察する目的で，テトラサイクリン とカルセインを 2 回投与した。投与時期は，インプラン 卜体埋植後 14 日目にテトラサイクリンを $30 \mathrm{mg} / \mathrm{kg}, 1 \%$ 水溶液として背部皮下に 1 回注射し，インプラント体埋 植後 21 日目にカルセインを $8 \mathrm{mg} / \mathrm{kg}, 3 \%$ 水溶液として 背部皮下に 1 回注射した（表 1 ).

\section{4. 観察項目}

1) 組織学的観察

組織学的観察は非脱灰研磨標本で以下のように行っ た. 各動物をエーテルの過剩吸収にて屠殺した後，ただ 


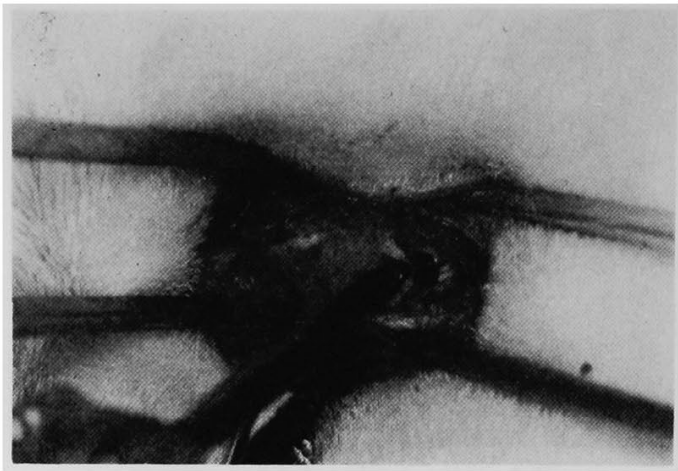

图 8 大腿骨と電極 (インプラント体) の結䋕固定

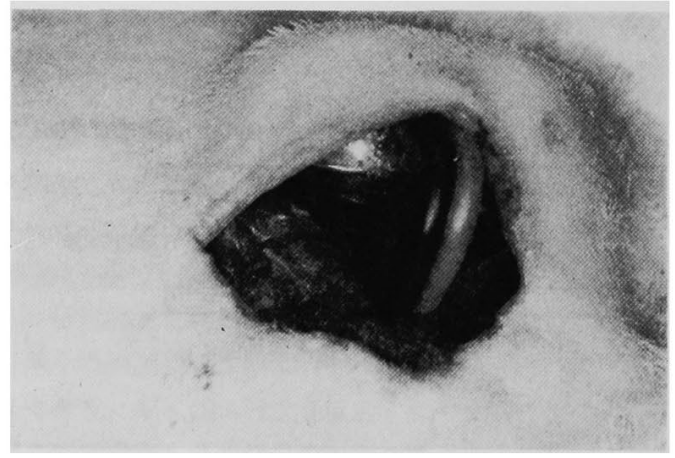

図 9 微小電流刺激装置の背部皮下への装着

ちに大腿骨を摘出し， 2 羽は，10\% 中性緩衝ホルマリン で固定し， 2 羽は Villanueva bone stain 溶液中で固定 およびブロック染色を行った. 固定完了後，インプラン 卜体の植立方向を確認するために軟 X線 装置 (Sofron) を使用し，FUJI X-RAY FILM を用いて，加速電圧 35 $\mathrm{kV}$, 管電圧 $5 \mathrm{~mA}$, 露出時間 3 分の条件で, 軟 $X$ 線写真 の撮影を行った，その後，大腿骨骨幹部を切り出し，水 洗, 脱水した後に，樹脂で包埋し，研磨標本を作製し た. 各標本の厚さは $150 \mu \mathrm{m}$ とした. ついで, 軟X線装 置を使用し, Spectroscopic Safty Film を用いて，加速 電圧 $15 \mathrm{kV}$, 管電流 $5 \mathrm{~mA}$, 露出時間 20 分の条件で, contact microradiograph (以下 CMR と略す) の撮影を行 った. さらに, 各標本を $80 \mu \mathrm{m}$ まで再研磨し、顕微鏡 用標本を作製後, 光学および螢光顕微鏡にて観察した.

2）電源および電極に関する検討

試作した微小電流刺激装置は 42 日間, 37 度の恒 温 槽 内の生理食塩水中に浸漬し, 出力電流の低下や漏電等が ないことを確認した、また，各モルモットを屠殺した 後, 電源部を摘出し, 実験開始時の電流值と比較した.

なお，今回の動物実験終了後に，微小電流刺激を行っ た際の，電極の金属腐食の程度を検討するために，in
34 卷 2 号 $(1990)$

表 1 テトラサイクリンおよびカルセインの投与時期

\begin{tabular}{|c|c|c|c|c|}
\hline & 14 & 21 & 28 & days \\
\hline$\mapsto$ & + & + & -1 & \\
\hline \multirow[t]{5}{*}{ Im } & TC & $\mathrm{CL}$ & $\mathrm{SC}$ & \\
\hline & & \\
\hline & \multicolumn{3}{|c|}{ TC : Tetracycline } & \\
\hline & \multicolumn{3}{|c|}{ CL : Calcein } & \\
\hline & \multicolumn{3}{|c|}{ SC : Sacrifice } & \\
\hline
\end{tabular}

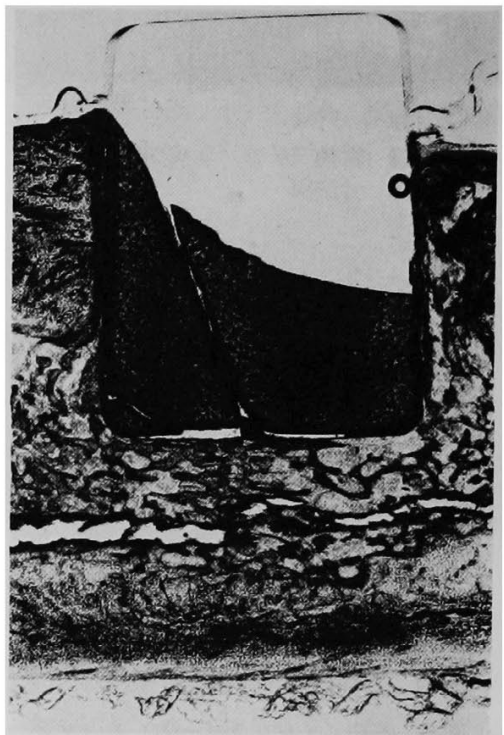

図 10 対照群のインプラント体周囲組織 (HE 染色) $\times 10$

vitro にて実験を行った，腐食の程度は，生理食塩水に 微小電流刺激装置および電極を浸漬し， $37^{\circ} \mathrm{C}$ の恒温槽 内で 28 日間, $10 \mu \mathrm{A}$ の通電したのちに，電極および生 理食塩水の着色の状態を観察することにより判断した。

\section{IV. 実験結果}

\section{1. 病理組織学的所見}

1）対照群について

インプラント体埋植後 28 日のインプラント体側壁上 部と，既存の皮質骨との間隙ならびにその周囲には，比 較的踈に新生骨が形成されていた（図 10)。また，CMR によればインプラント体の側壁下部には，島状に散在し た新生骨が形成されていた（図 11).

2）実験群について

陰極周囲：インプラント体埋植後 28 日のインプラン 卜体の周囲全域に，対照群と比較して広範囲に多量の梁 


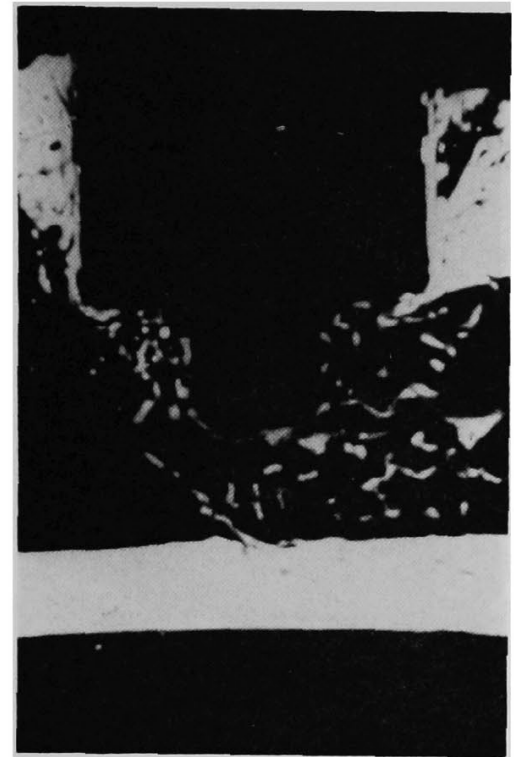

図 11 島状に形成された対照群の骨梁配列 を示す CMR $\times 10$

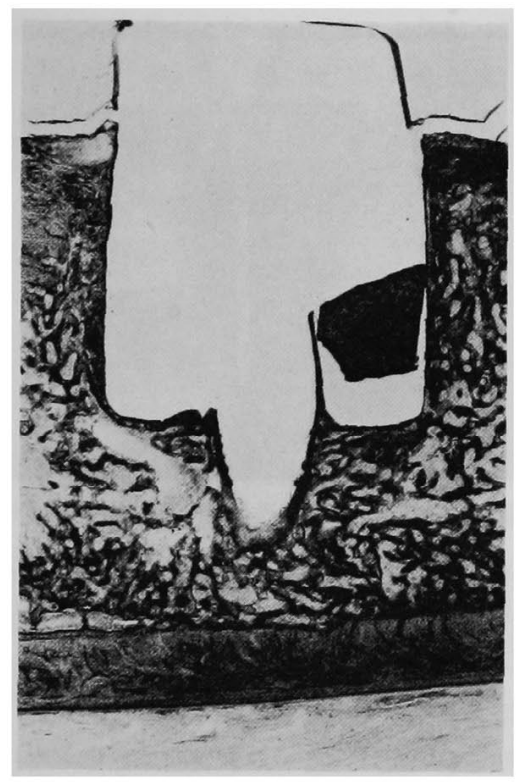

図 12 陰極のインプラント体周囲組織 (HE 染色) $\times 10$

状新生骨の形成がみられ，新生骨とインプラント体の間 には線維性結合組織層の介在は認められなかった（図 12).

また, CMR によりインプラント体周囲の骨梁の配列 を観察すると，インプラント体表面近くの骨梁はインプ ラント体に平行に形成される傾向にあった.さらに，イ

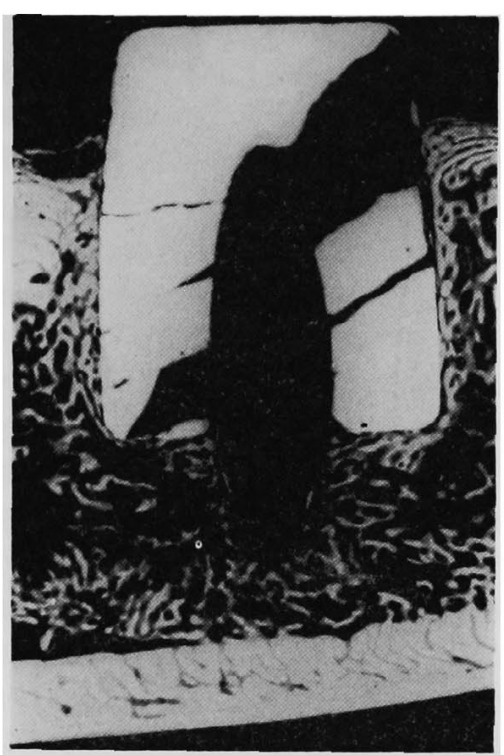

図 13 放射状に形成された陰極の骨梁配列 を示寸 CMR $\times 10$

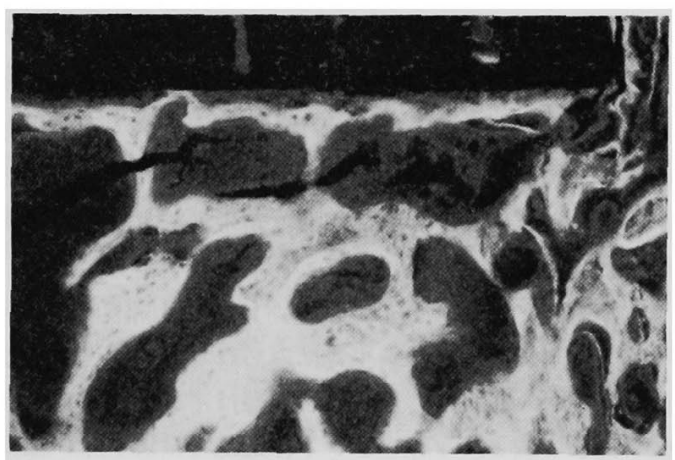

図 14 新生骨梁のほぼ全城がテトラサイクリンに標識さ れた螢光頙微鏡所見 (villanueva bone stain) $\times 20$

ンプラント体底部にも繖密に配列した梁状の新生骨を認 め，その骨梁はインプラント体底部に対して平行に配列 する傾向にあった. また, 底部の突出した電極に対して は垂值な方向に梁状新生骨が形成されており，電極を中 心として放射状にみられた（図 13）。このように，イン プラント体周囲の新生骨は対照群と比較して広範囲に, そして多量に形成されるのみならず，その形成される骨 梁の配列方向も異なっていた.

新生骨の石灰化の状態を螢光顕微鏡により钼察する と，インプラント体周囲に形成された梁状新生骨は，ほ ぼ全体が実験開始 14 日目に投与したテトラサイクリン に標識されており，実験開始 21 日目に投与したカルセ 
$70-314$

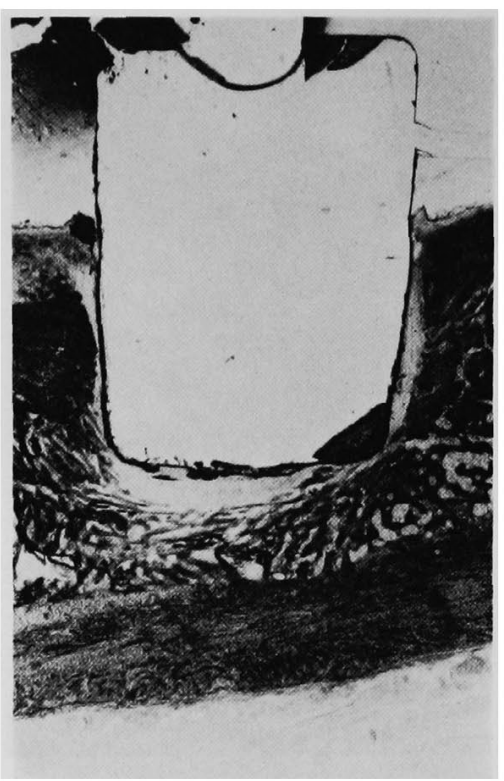

図 15 線維性結合組織に覆われた陽極の インプラント体 (HE 染色) $\times 10$

インに標識された部位は，ほとんどみられなかった（図 14)。な㧍、インプラント体と既存の皮質骨との間には 埋植時にかなりの間隙を生じてしまったものもあった が,このような例でもその間隙は新生骨により完全に满 たされていた.

陽極周囲：皮質骨とインプラント体との間隙には, 対 照群でみられたような新生骨はみられず，線維性結合組 織の介在がみられた.この結合組織はインプラント体側 壁下部まで続き，インプラント体底部では上り厚い線維 性結合組織の層となっていた（図 15)，このように，陰 極周囲ではインプラント体表面に直接骨が接していたの に対し，陽極ではインプラント体周囲に線維性結合組織 がみられた. また，CMR にて観察すると，インプラン 卜体周囲の線維性結合組織の外周には対照群に比して緻 密な梁状骨が，広範囲に形成されていた（図 16).

\section{2. 電源部および電極に関する観察結果}

各モルモットを居殺した後, 微小電流刺激装置からの 電流が実験当初のものと大きく变化していないことを確 認するために, 電源部を摘出し, 刺激電流值を測定した 結果, $9 \mu \mathrm{A}$ から $10 \mu \mathrm{A}$ の閒であり, 実験開始時と大き な変化はなかった。

また, 電極の材料としてチタン線と歯科用白金加金線

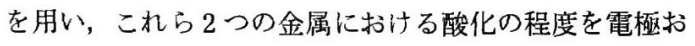

34 巻 2 号 (1990)

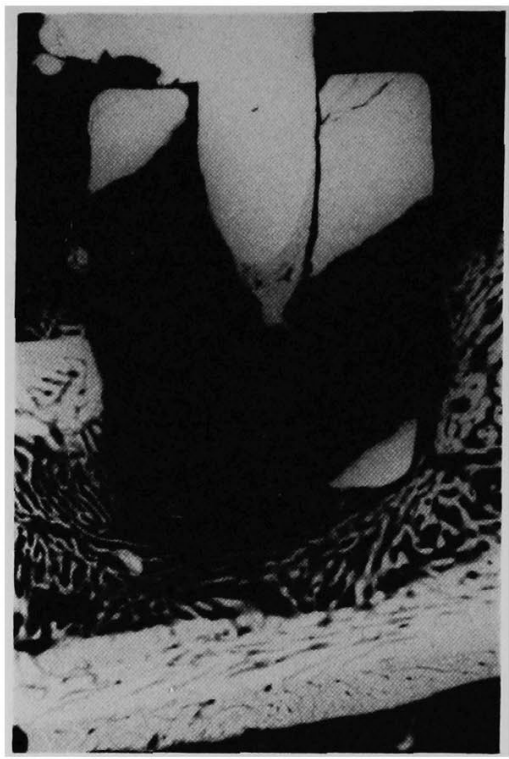

図 16 陽極のインプラント体周囲の CMR $\times 10$

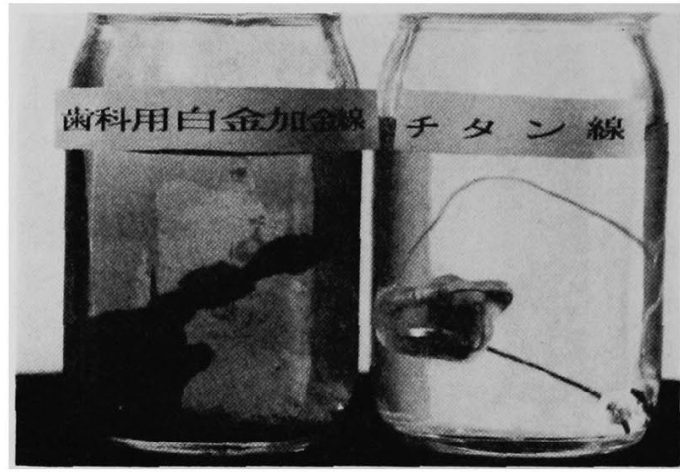

図 $1710 \mu \mathrm{A} ， 28$ 日間通電後の電極の腐食状態

よび生理食塩水への着色の程度で比較した. その結果, 歯科用白金加金線はチタン線に比較して電極および生理 食塩水一の着色の程度が強かった（図 17). 陰極におい ては, 電極表面で大きな変化はみられなかったのに対 し，陽極においては，2つの金属間で変化がみられた. すなわち，歯科用白金加金線からなる陽極は，電極自体 の形態は変化していなかったが, 電極表面に茶褐色の着 色がつよくみられた. チタン線からなる陽極には, 電極 自体の形態の変化および電極表面への着色はほとんどみ られなかった。 


\section{V. 考察}

骨内インプラント法において、インプラント周囲の骨 は埋入当初の初期固定に十分であり, 最終的にはインプ ラントに加わる機能的負荷を支持しうることが必要であ る゙!。のように, インプラント周囲の骨は早期に形成 されることが望ましいが，インプラント体周囲の骨形成 を促進するための積極的な試みは少ない4 6)。そこで, 骨形成を促進する10 23) と思われる微小電流刺激を骨内 インプラント周囲に応用することを考えた．また，微小 電流刺激を効果的にインプラント周囲組織に与えるため に，電極を兼妏備えたインプラント体の試作および微小 電流刺激装置の小型化を行った。これらの装置を用いて モルモットの大腿骨に微小電流刺激を与え, その微小電 流刺激が，インプラント体周囲の骨形成に及ぼす影響に ついて病理組織学的に検討した.

\section{1. 実験方法および装置について}

微小電流刺激装置およびインプラント体は，微小電流 刺激を骨内インプラント法に応用するにあたり，口腔内 の条件を想定して作製した．まずはじめに，口腔内の狭 小な位置に微小電流刺激装置を置くために, 装置の小型 化を行った.この小型化は電源部と FET の部位で行っ た. すなわち, 電源部ではボタン状の小さな電池を用い た. また，ボタン状電池の選択にあたっては，水銀電池 および酸化銀電池を用いて，それぞれの微小電流刺激装 置を $37^{\circ} \mathrm{C}$ の恒温槽内の生理食塩水中に浸漬し出力電流 値の測定を行った. その結果, 実験当初は $10 \mu \mathrm{A}$ の電 流值であったのに対し， 6 週後に測定すると酸化銀電池 を用いた微小電流刺激装置は, ほほ $10 \mu \mathrm{A}$ の電流值を 示したが，水銀電池を用いた場合は，2３ $\mu \mathrm{A}$ まで低下 していることが判明した．このことから，本実験装置に は電圧の低下までの期間が長い酸化銀電池を使用した. また, 適用した刺激電流値が抵抗の変化する骨内でも維 持されるように, FET を用いた定電流回路10)を用いた. 定電流回路においては，2つの FETが一体となった dual FET が主に用いられているが，市販されている dual FET はやや大きめのサイズとなるため, 本実験で は単独の FET 2 個をろう着して dual FET とし, 市販 のものよりも小型なものとした，また，装置の組み立て にあたっては，小型化のために回路用の基板は用いない で行った. その結果, 装置は重量約 $5 \mathrm{~g}$ で, $9 \times 13 \times 18$ $\mathrm{mm}$ 程度の大きさとなり，小型化がなされたと思われ
た.

刺激電流の大きさに関して保田は，刺激電流における 電気エネルギーの大きさの違いにより, 電極周囲には異 なる組織反応がみられ，エネルギーが小さいときには骨 性の反応を生じ，大きいときには線維性の反応がみられ ると報告した ${ }^{9)}$ ささらに，骨性の反応を生じさせるため の微小電流刺激の至適電流に関する研究がなされ，1〜 $20 \mu \mathrm{A}$ と幅をもった值が示されている ${ }^{10,12,18,20)}$. 本実験 では骨内インプラント法への応用を考え、線維性の反応 を引き起こさないように, 至適電流值のなかではやや低 めかと思われる $10 \mu \mathrm{A}$ を適用して骨髄内部から微小電 流刺激を行った. また, 微小電流刺激を与える電極は, インプラントと埋植䆚壁との間隙になるべく近い部位に 刺入することが望ましいため，インプラントと電極を一 体化した構造のものを新たに考案した. すなわち、イン プラント体の外壁は HAP で覆い, 電極の絶縁体の役目 と同時に骨内インプラントとしての役目も兼ね備えたも のとした.このことにより，埋植部位に直接電極を刺入 することが可能となり，インプラント体埋植と同時に電 極が骨内に挿入されるため，電極刺入のための手術を必 要としない電極とした．また，微小電流刺激による組織 反応は Friedenberg ら ${ }^{11}$ により電極周囲に限られると 報告された．このことから刺激部位を骨髄内とするた め, 皮質骨部は電極周囲を絶縁体である HAP で覆い, 骨髄内部で $1 \mathrm{~mm}$ の電極を露出する形態とした.

次に, 刺激電流の材料としては入手が容易で, 周囲を HAP で覆う作業に耐え得る硬さを有する歯科用白金加 金線を試験的に用いた，しかし，標本作製時に電極周囲 を肉眼で観察すると，陽極周囲が茶褐色に変色してい た.この理由として陽極の金属腐食が疑われたので, 電 極の材料として歯科用白金加金線と表面が不動態化され やすい ${ }^{27)}$ チタン線を選択し, 生理食塩水中で金属腐食の 程度を比較した．その結果，チタン線のほうが金属腐食 が少ないと思われた.これらのことから電極としては歯 科用白金加金線よりチタン線の方が適していると思わ れ，現在，検討中である.

\section{2. 病理組織学的観察結果について}

微小電流刺激やインプラント体埋植によって形成が促 された新生骨梁を，既存の骨梁と区別して観察するため に，実験部位として生理的状態では，ほとんど海綿骨は みられないモルモットの大腿骨骨幹部中央付近を用い た. 今回の実験における対照群のインプラント体周囲に は，島状に散在した新生骨がみられた。このことからイ 
ンプラント体埋植によってのみでも，インプラント体周 囲の骨形成はある程度引き起こされたと.思われた。一 方, 島状に新生骨が形成された対照群に比較して実験群 では，陰極・陽極ともインプラント体周囲の梁状新生骨 が著明に多く認められた.このことから微小電流刺激は インプラント体周囲の骨形成を促進したと思われた. ま た，形成された梁状骨を螢光顕微鏡により観察すると， ほぼ全域がインプラント体埋植後 14 日目に投与したテ トラサイクリンに標識され, カルセインにはほとんど標 識されていなかった.このことから新生骨梁の形成は, 主にインプラント体埋植後 14 日前後に行われていたと 思われた。この結果は, 松永らが家鬼を用いて 3 日から 56 日までの電気刺激を行い 14 日には ALP 活性值が著 明に増加し，電気仮骨をみたという報告22)と一致する。

また, 新生骨は陰極・陽極ともに電極を中心として放 射状に形成されており，片岡17) や大野 ${ }^{23)}$ が報告したよう に, 髄腔の新生骨梁は電気力線の方向に影響を受けてい たと思われた. このように実験群では, 微小電流刺激に より広範囲に多量の骨形成がなされたのみならず，その 形成の方向も対照群と異なっていた.

陽極周囲と陰極周囲の骨形成に関して比較すると, 陰 極のインプラント体には緻密に配列した新生骨梁が直接 接していたのに対し，陽極のインプラント体周囲には， 線維性結合組織を介して緻密に配列した新生骨梁がみら れた.この線維性結合組織の介在により，周用の緻密な 骨梁は, インプラント体の支持組織としての働きはなさ れないと考えられた.このことから，骨内インプラント のように外力を骨に伝達する目的をもったインプラント 体周囲に微小電流刺激を応用するにあたっては, 刺激電 極として陰極のみを用い，陽極は軟組織内に置くなどの 処置が必要であると思われ，この点は今後の研究課題と される. 以上の結果から，微小電流刺激を骨内インプラ ント法に応用することにより骨形成を促進させる可能性 が示唆された。

\section{VI. 結 論}

今回試作した電極を兼ね備えたインプラント体をモル モットの大腿骨に埋植し, 小型化した微小電流刺激装置 を用い，電流刺激をあたえ，インプラント体周囲の骨形 成を促進させる実験を行った. その結果, 以下の結論が 得られた。

1. 微小電流刺激によりインプラント体周囲には, 対 照群に比較して広範囲に多量の骨形成がみられた。
34 巻 2 号 $(1990)$

2. 微小電流刺激により形成された新生骨の骨梁の配 列は対照群と異なり，インプラント体に近接した部位で はインプラント体に平行に，そしてインプラント体から 離れるに従い，電極を中心として放射状であった。

3. 陰極と陽極における骨の形成状態を比較すると陰 極では，線維性結合組織が介在することなくインプラン 卜体表面に緻密な梁状新生骨が認められたのに対し，陽 極では，インプラント体周囲に線維性結合組 織がみら れ，その外周に緻密な梁状の骨が認められた.

4. 電極の材料としての適性を齿科用白金加金線, 千 タン線において金属の溶出の程度から比較した結果, チ タン線の方が優れていた。

5. 以上の結果から今回試作した微小電流刺激装置と インプラント体は，骨内インプラント法に応用できる可 能性が示唆された.

\section{文献}

1) Adell, R., Lekholm, U. and Rockler, B. et al : A 15-year study of osseointegrated implants in the treatment of the edentulous jaw, Int J Oral Surg, $10: 387 \sim 441,1981$.

2）小木曾誠, 金田浩之, 塩田 真ほか：Apatite 2-piece implant, 第 3 報 臨床治験について, 補緅誌, $32: 523$ $533,1988$.

3）添島義和：ITI インプラント法 (一回法) の適応と思われ る臨床ケース, オーラル・マキシロフェイシャル・インプ ラント, $2: 381 \sim 388,1989$.

4）。益田高行：Apatite implant 適用を目的とした顎骨内部棈 造の改善に関する実験的研究, 口病誌, $56: 289 \sim 313$, 1989.

5）井上 孝, 下野正基, 山村武夫：インプラントと歯根膜, 歯界展望, $7: 1027 \sim 1037,1986$.

6）鱼島勝美 : Apatite implant 適用を目的とした顎堤形態の 改善に関する実験的研究，口病誌, $56: 314 \sim 346,1989$.

7）保田岩夫, 加藤常行, 佐多徹郎ほか：骨の圧電気現象, 日 本外科学会雑誌, $54: 449,1953$.

8）保田岩夫, 原治, 岡田 皖ほか: 仮骨形成に関する力 学的考察, 日整会誌, $27: 224 \sim 225,1953$.

9）保田岩夫, 野口和彦, 飯田 殭 : 電気的仮骨の応用, 日整 会誌, $29: 351 \sim 353,1955$.

10) Friedenberg, Z.B., Andrews, E.T. and Smolenski, B.I. et al: Bone reaction to varying amounts of direct current, Surg Gynecol Obstet, $131: 894 \sim 899,1970$.

11) Friedenberg, Z.B., Roberts, P.G. and Didizian, N.H. et al : Stimulation of fracture healing by direct current in the rabbit fibula, J Bone Joint Surg [Am], 53-A : 
$1400 \sim 1408,1971$.

12) Friedenberg, Z.B., Zemsky, L.M. and Poliis, R.P. : The response of non-traumatized bone to direct current, J Bone Joint Surg [Am], 56-A : 1023 1030, 1974.

13) Liboff, A.R., Rinaldi, R.A. and Lavine, L.S. : On electrical conduction in living bone, Clin Orthop, 106 : $330 \sim 335,1975$.

14) Stefan, S., Sansen, W. and Mulier, J.C. : Experimental study on the electrical impedance of bone and effect of direct current on the healing of fractures, Clin Orthop, $120: 264 \sim 267,1976$.

15）高橋栄明, 外川 裕, 今野俊幸ほか: 微小電流による骨の 吸収への影響, 整形外科基礎科学誌, $4: 145 \sim 154,1977$.

16) Yasuda, I. : Electrical callus and callus formation by electret, Clin Orthop, $124: 53 \sim 56,1977$.

17）片岡 護: 電流が仮骨形成, 細胞の代謝性と仮骨の性状に 及ぼす影響, 神奈川歯学, $15: 540 \sim 560,1981$.

18）大野朝也：微小電流刺激が笐骨骨欠損創の治療経過に及ほ 寸影響に関する実験的研究, 歯科学報, $82: 1323 \sim 1353$, 1982.

19）久保田浩三：歯槽骨の人工的骨欠損におよぼす微小電流刺 激の影響に関する実験的研究, 九州歯会誌, $36: 64 \sim 81$, 1982.

20）外川 裕：長管骨骨皮質の Internal remodeling に及ぼす 微小直流電流の影響に関する実験的研究, 日整会誌, 57 :
$817 \sim 835,1983$.

21) Takahashi, H., Togawa, Y. and Hanaoka, T. et al : The effects of various types of microelectrical current waveform on bone formation in internal remodeling in dogs, edited by Fukada, E. et al, Bioelectrical repair and growth, 184 190, Nishimura, Niigata, 1985.

22）松永俊二, 酒勾 崇, 吉国長利ほか: 微弱值流電気刺激に よる喵有内仮骨, 電気仮骨部アルカリフォスファターゼ活性 值の経時的変化について, 生体電気刺激研究 会誌, $2: 67$ $\sim 71,1988$.

23）大野 敬：骨原性細胞株 MC3T3-E1 に対する微小電流刺 激の効果, 日口外誌, $34: 15 \sim 23,1988$.

24) Bassett, C.A.L., Mitchell, S.N. and Gaston, S.R.: Treatment of ununited tibial diaphyseal fructures with pulsing electromagnetic fields, J Bone and Joint Surg [Am], 63-A : 511 523, 1981.

25) Ascherl, R., Lechner, F. and Blumel, G. : Electrical stimulation of low frequency range in case of Pseudarthroses, Survey of 350 cases Reconstr Surg Traumatol, $19: 106 \sim 112,1985$.

26）臼井 宏, 峯崎孝俊: 骨折に対する電気刺激療法の適応に ついて, 生体電気刺激研究会誌, $2: 9 \sim 12,1988$.

27）川原春幸：生体用金属材料の塹性，金属，50：45 50, 1980. 